\title{
Role Conflict among Female medical Career women: who bridges the Gap?
}

\section{DOI: http://doi.org/10.26758/8.1.14}

Oluyemi Joseph (1), Yinusa Mohammed (1), Bashiru Salawu (1), Abdulateef Raji (1), Emmanuel Atolagbe (1) and Adejoke Joseph (2)

1. Department of Sociology, University of Ilorin, Ilorin, Nigeria

2. Department of Medical Microbiology and Parasitology, Bowen University, Iwo, Nigeria.

Address correspondence to: Joseph Oluyemi, Department of Sociology, Faculty of Social Sciences, University of Ilorin, Kwara State Nigeria. Phone number: +234/018034205013. Email: josepholuyemi1@gmail.com.

\begin{abstract}
Objectives. This study investigates the conflicting roles of female medical career women in Nigeria. The objectives of the study include: to know who fills the gap as a mother and wife while they are away at work; to know if they provide the needed emotional and psychological support for their families?; to determine if these conflicting roles affect their health and who is to blame?

Materials and Methodology. The study was conducted among married female medical doctors in three Tertiary Hospitals in Nigeria. The study employed qualitative research method in which data was retrieved through in-depth interviews with 15 participants selected through multi-stage sampling method.

Results. Findings revealed that relatives, the school, and caregivers play the role of the female medical career women when they are at work while communication by career women with their families when they are not at home is done through phone calls, text messages, video calls, WhatsApp chats. The majority of the participants is unable to meet up with the role of providing emotional and psychological support for their families because of their busy schedules at work, which also affects their health adversely.

Conclusion and Recommendation. Most of the participants interviewed were found unable to effectively occupy their roles as mothers and wives in the family because of their career. The study recommends that, since the role of women in the family cannot be overemphasized and at the same time women are expected to pursue careers of their own choice, women in Nigeria should endeavor to maintain a balance in their roles as career women at work and as wives in the family.
\end{abstract}

Keywords: caregivers, relatives, female medical doctors, career women, role conflict

\section{Introduction}

The family is the smallest unit of a society and the connection between individuals, the family, and the society cannot be over-emphasized. Historically, the family was typified by gender roles, where men were breadwinners engaged in paid labor work and women specialized in unpaid domestic work and caring for the family (Crompton, 1999). But in recent time, the story has changed as more women are becoming breadwinners in families and women are no longer housewives but work alongside their husbands in the labor market (Lewis, 1997; Rubery et al., 1998). Undeniably, the participation of women in the labor force is now a global phenomenon that 
has developed significantly over the past several decades such that, the majority of women including those with toddlers now work as paid labor in previously male-dominated jobs (Kroska, 2004).

The story is not different in Nigeria. From time immemorial, the Nigerian society has been a patriarchy society (Aina, 1998), where men dominated women (Stacey, 1993; Kramarae, 1992; Lerner, 1986; Humm, 1989; Aina, 1998), and do not participate in domestic work since such tasks are considered to be the exclusively reserved to women (Bernard, 1981; Aweda, 1984; Carrigan, Connell and Lee, 1987; Stocvk, 1995; Silberschmidt, 1999). According to Makama (2015), women constitute about half of the population in Nigeria and are known to play vital roles in the family and the society at large, which cannot be undermined. Men were the main breadwinners, while women were saddled with domestic responsibilities and the socialization and monitoring of young children (Adepoju and Mbugua, 1997). But in recent time, the division of labor in the family in terms of gender roles is gradually disappearing. Women educational attainment has soared over the years and as such, gender inequality in formal employment has drastically declined (Wusu and Abanihe, 2007).

The economic hardship prevailing in the country is also gradually making it a norm for women to make a substantial contribution to family income in order to cater adequately for family needs, and thus, women are increasingly taking up roles that were traditionally reserved for men (Odunaike, 2012). A number of studies have attempted to downplay the magnitude of the contributions of wives earnings to family income (Hansen, 1991). Nevertheless, wives' incomes are seen as benefiting the family in many ways. As such, women now play multiple roles in the society since women are the significant agent of household chores, socialization, and childbearing and have to still carry out their economic roles as formal employees. Therefore, due to the rising number of mothers now in paid employment, the demands at workplaces are increasingly harming the wellbeing of their children (Ering, Akpan and Echiegu, 2014).

Today, educated women are found in virtually all professions, including medicine, and, as such, the care of young children is now being transferred to the larger society (Fapounda, 2014). Women have begun to experience conflict with the competing roles they play at their workplaces and that of the family (Lussier, 2002). Balancing work and family life is increasingly becoming an issue because the family is negatively affected (Aaron-Corbin, 1999; Gryzwacz and Carlson, 2007), as these two domains, though different, are sometimes interdependent and strongly influences each other (Odle-Dusseau, Britt and Bobko, 2012). Both men and women may be said to experience inter-role between work and family (Walker, Wang and Redmond, 2008), women typically assume more family responsibilities than men (Pilinger, 2002). Managing these roles in a patriarchal society like Nigeria may, however, be difficult (Rehman and Roomi, 2012).

According to Okonkwo (2012), in Nigeria for example, the domestic duties of tidying home, cooking for the family, laundry work, and childcare are exclusively women's job, many of whom are also engaged in full-time paid employment. The psychological consequences of combining these roles squarely fall on women (Jacobs and Gerson, 2004), as the Nigerian society still places a premium on the traditional female role with the cultural approval of qualities such as submissiveness, subservience, and supportiveness (Kitching and Woldie, 2014). In particular, women are faced with the problem of multiple role conflict when conflicting demands of marriage, children and work impinge on their work (Aaron-Corbin, 1999). Research has shown that coordinating work and family life is quite difficult for women (Emslie and Hunt, 2009), but married women find it even more problematic (Dyrbye et al., 2014). Therefore, failure to achieve a balance between the work and family domain might have on health, general wellbeing on women (Emslie, Hunt and Macintyre, 2004). 
Research has also shown that finding an acceptable balance between career and family life is a difficult challenge for many female doctors (Verlander, 2004). The medical profession has commonly been characterized by long working hours and the obligation to put patient welfare above personal needs and family responsibilities Gjerberg (2003), which is considered a challenge, especially for a practicing female doctor. It is against the background that this study is being conducted.

\section{Theoretical Orientation}

The study was explained with the Role theory. Role Theory was postulated by Ralph Linton, an American Anthropologist, in the 1930s (Gordon, 1998). The theory was a means for analyzing social systems, in which, roles were conceived as the dynamic aspects of societally recognized social positions or statuses. Role theory argues that human behavior is guided by expectations held both by the individual and by others in the community. It assumes that individuals are members of social positions and hold expectations for their own behaviors and those of other persons. According to the theory, people take distinct positions in the groups they form; these positions are roles, with a set of functions that are molded by the expectations of others. The theory emphasizes on role conflict, which occurs when a person is expected to simultaneously act out multiple roles that carry contradictory expectations. The theory states that role conflict occurs when there are incompatible demands placed upon an individual, such that compliance with all these demands would be difficult. Individuals thus experience role conflict when they find themselves pulled in various directions, as they try to respond to the many statuses they occupy.

Resting on the theory, it can be assumed that female married medical doctors would experience role conflict in the process of occupying various statuses. For instance, role conflict would occur while trying to be a mother and a wife in the family and a doctor at work.

Doctors generally experience a high level of stress as a result of the increased workload with low control over the job (Fuß al., 2008). As a result, a number of doctors experience psychological problems like anxiety, depression, irritability, fatigue, sleep deprivation and substance abuse (Nogueira-Martins, Stella and Nogueira, 1997; Levey, 2001). Often, doctors have to attend to emergency cases and patients with life-threatening illnesses which are usually complicated by their ever busy schedules and disproportionate doctor-patient ratios. The Nigerian health care system is no exception to this. The system is bedeviled with underfunding, dilapidated structures, poor staffing, and inadequate equipment thereby complicating the ordeals of doctors in the system (Onasoga, Ogbebor and Ojo, 2013; Etim, Bassey and Ndep, 2015).

Female doctors have been recognized as core professionals everywhere they are found, whether married or single (Amazu, 1995). However, these conflicting roles have been found to be more demanding for women (Wolfe, 2017). Though both men and women usually experience role conflict between work and family (Walker, Wang and Redmond, 2008), it is assumed that women typically assume more family roles than men (Pillinger, 2002). Research has shown that combining work and family obligations could be difficult for female medical doctors in a patriarchal society like Nigeria (Rehman and Roomi, 2012). In Nigeria, for example, the domestic chores of cooking, tidying up of the house, laundry, and childcare fall basically on women who need to combine these with their career and when a balance cannot be struck between both roles as a mother and a career woman, one suffers at the expense of the other, thus constituting a conflict between their role at home and in their chosen career. In the same time, men take up more masculine roles, thus generating role conflict for those that are working like female medical doctors. 


\section{Materials and Methodology}

This study employed the qualitative method of inquiry, which includes an exploratory and explanatory case study approach to unravel the difficulties confronted by the Nigerian female medical doctors in their attempt to occupy the roles of wives and mothers in the family as well as pursuing their career as Doctors.

The particular choice of a qualitative approach was informed to gain insight into the reality of the role conflict experienced among female doctors in the Nigerian context. According to De Ruyter and Scholl (1998), qualitative research method provides researchers with knowledge of what people think about a particular subject and what makes their thinking differ from other people's thoughts.

The study focused on a group of participants, which were married female medical doctors. The study was conducted among female medical doctors in three tertiary hospitals in Nigeria, which include: Bowen Teaching Hospital, Ogbomoso, Oyo State, Nigeria; Ladoke Akintola University of Technology, Ogbomoso, Oyo State, Nigeria; and University of Ilorin Teaching Hospital, Ilorin, Kwara State, Nigeria. The study population was purposively selected in order to have a spread of doctors in various cadres and specialties.

15 married female medical doctors, selected through multi-stage sampling method, were involved in the study cutting across House officers, Medical Officers, Residents, Senior Residents, and Consultants, while information was retrieved from participants through unstructured in-depth interviews. Participants' consent was sought before the interview was conducted and informants' identities were treated with anonymity to gain the participants' confidence. The participants were given the opportunity to opt out of the research before or during the interview; therefore, they were given free will to participate in the research. To protect the confidentiality of the participants, the identities of the participants were identified with their position in the hospital.

\section{Results}

\section{Who Bridges the Gap?}

Most of the participants in the study had one person or another who stood in for them to cater for their children and husbands when they were away at work. Findings revealed that, because of the conflicting role of doctors at work which afforded them very little time to attend to the family responsibilities, many of the participants had to employ the service of caregivers, relatives like mothers-in-law, sisters-in-law and their mothers, to fill the gap and play their role in their absence as mothers and wives at home. Some participants had this to say.

"Raising up children as a doctor is not easy at all.... I had my first child as a house officer. My child was just three weeks old when I took up the job and it wasn't easy at all. I had to bring in my sister to come and stay with me until the child was six months because I had to do exclusively for six months breastfeeding so most time I had to do breast expression because I couldn't go to feed my baby myself. When my sister left for school, my mother in law came in to stay for a while but because she is a civil servant she had to also go back to work, so, I had to rely on the services of caregivers. As for my husband, he is a teacher so he has all the time; he does all the house chores and takes care of the children and the home when I am not there..." (Senior Registrar, LAUTECH). 
Another female medical doctor has this to say:

"Being a doctor, a wife and mother at home has been very difficult and very challenging. The late nights, there are times you have to travel, go for conferences, you have to read for exams, you really don't have the time for the children and the family, you have to depend on house helps, family members to help you care for the children and the family generally. So it's not been easy ... it's really difficult, at the initial stage it was much more difficult but as you go higher in the profession and become more senior you have more time to yourself and the family. When my children were growing up, I wasn't there at all, my mother had to stand in for me, I was never around, in fact, some of my children's teachers do not know me, they hardly ever see me, sadly my children refer to my mother as their own mother...."(Consultant, UITH).

Another participant also had this to say:

"Unfortunately for us female doctors, our reproductive age coincides with the prime years of our career period and you cannot leave one or another. At times my children come home with assignments that as a mother, I should be able to put them through but I am not always there. Recently, my child had an exam and I just couldn't help. I work for more 70 hours per week, especially when I am on call, where on earth will I have the time to attend to my family, my husband plays my role at home (laugh), he bath the children, feed them and take them to school. At times when I get home late in the night, my children would have slept, it's really sad..... Although anytime I am at home, I make up for the time I have not been around. I will ask my kids how has been your school. What has been happening to you and for my husband I ensure I give him all my time, the little time I spend at home with him, I don't do any other thing than to face my husband and children......"(Senior Registrar, LAUTECH).

\section{Do you Provide Emotional and Psychological Support for the Family?}

The majority of the participants could not provide their children and husbands the necessary emotional and psychological support because they are hardly there. Although they claimed that the bond is there, other mediums such as telephone call, text messages WhatsApp chats were employed in providing these roles while their physical presence at home was lacking Take a look at this:

"...Well am trying my best, my child is still a young child growing, when am around I do my best to make up for the lost time, like today am not working at the moment as it were, we have played football to make up for those times am not around and when he sees me, he runs to me so I think the emotional bond is there. As for my husband, he is also a doctor and he is also not always around but we try to communicate often through WhatsApp, video calls, text messages and emails to ensure that the emotional and psychological support is not lacking, hmmm.... Although the physical presence is not there, they say «out of sight is not out of mind» ... laugh" (Resident, BUTH).

Similarly, another participant has this to say:

"If not for my present posting that takes me out of town, I would have been able to meet up with this obligation. But at the moment, I can say that am lacking in this regard, especially to my child. 
Similarly, to my husband, I can equally say that I am lacking, although I am trying, whenever I am around, to make up for the time I am not around" (Resident BUTH).

\section{Does this Role Conflict affect your Health?}

The majority of the participants experience adverse health effects as a result of the conflicting roles. Some complained of the stress involved, while some others confessed that combining this role affected them both psychologically and physically. This is the experience of some of the participants:

"Yes...the work is quite demanding and stressful, especially when you have to combine it with family responsibilities. Balancing the two could be hectic, you know nobody wants to know that you are married or you have children and so you cannot live up to your responsibilities at work. Sometimes, it could bring emotional challenges, mood change, depression and all that. I work like .....60 hours per week, when you are on weekend call for example, it starts Saturday morning and ends 7:59 on Monday morning and you are expected to be at work again, so maybe the only time you have to stay off work is when you have to go freshen up and eat. It comes with dull headache sometimes, body aches and all that ....uhhh" (Senior Registrar, LAUTECH).

Another participant has this to say:

"Combining the role of a doctor at work and as a mother and wife at home is quite stressful, teaching medical students and also trying to attend to patients is time consuming and then coping with the home front is not easy. At times, I get back home very tired.... Despite this, I still have to play my role as a mother and as a wife; no matter how tired I am, I still have to prepare the meal for my children.... Hmmm, it could be quite stressful" (Consultant BUTH).

In the same vein, see what this participant had to say:

"Well...at the initial stage of my training as a resident, it wasn't easy combining the roles, it affected me psychologically, it was too demanding, I didn't even have time for myself. Unfortunately nobody cares you are married or you have children, everybody just wants the work done, except maybe when you drop down sick that is when people will say, ..... ahhh you should have talked .... Ok go on two days leave and come back and finish the job, it's really crazy you know...." (Resident BUTH).

\section{Who is to Blame?}

Although some of the participants see themselves in this conflicting role because they chose to follow a career path to improve their status in the society, some other saw it as a calling. Above all, the majority sees this conflicting role as a means of complimenting family income. Here are some opinions that participants expressed:

"As a working mother, I think it is a choice that I have made as a child, I have always wanted to be a doctor and work as a wife in the future, although being a career mother and wife affords me the opportunity to add to the income of the family. If I wasn't working my husband salary would have been able to cater for the family needs" (Resident BUTH). 
Another participant with a similar view declared:

"...Actually, I believe medicine is a calling; since I was a child it has always been medicine, medicine, if I wasn't a doctor or working, I will not be fulfilled, so I love medicine. I love to work, that is why I am doing medicine. If I am not working, my husband salary would have just been ok for us but because I am working, I am complimenting the family income. I am working to buffer the family income so that we can enjoy the best of life as a family" (Consultant, BUTH).

Also, another participant had this to say:

"Hmmm... I am working to further support my family, my husband, his family, and mine. We have a lot of people to care for from both me and my husband's family, $80 \%$ of our younger ones are still in school and they depend on us for their upkeep, which we have to support. At the end of the day, it's not my income but basically "our income". Although, as a doctor, it's more of a calling and capacity building as well as to improve my status and esteem as a woman." (Resident, BUTH).

\section{Discussions}

The study has been able to explore the conflicting roles of female doctors in Nigeria as professionals and wives and mothers in the family. This study, thus, illuminates the dilemma of Nigerian female doctors in their efforts to achieve work-family balance. The findings revealed that, as a result of the role conflict, the majority of female doctors is not able to effectively occupy their role as mothers and wives in the family. Findings revealed that for most of them, the domestic role is being played by their relatives, i.e. mothers, mothers-in-law and sisters; sometimes this is done by caregivers, the school and even by their husbands. This is consistent with the previous study conducted by Fapounda (2014) who opined that the care of young children does not take place exclusively within the family group, but it is now being transferred to the larger society.

Further findings from the study revealed that participants are unable to provide emotional and psychological support for their children and their husbands, perhaps because medical doctors have the obligation to put their work duties, such as patients' care, above their families' responsibilities (Gjerberg, 2003). Most times of the day they are away at work and such role is played by teachers and the significant others. Unfortunately, some professions like medicine do not fit the typical work pattern of 9pm-5pm (Burke, 2009); the work pattern in the medical profession is characterized by long working hours (Gjerberg, 2003), and sometimes they work during vacations and holidays (Perlow and Porter, 2009), all of which further make achieving this very difficult (Johnson, 1991). Although some participants claimed they make the best use of the limited time at their disposal to catch up with what they have lost, this may not be sufficient to meet the psychological and emotional needs required for the bonding and attachment expected in the family.

Furthermore, findings from the study revealed that the conflicting is detrimental to their health. Health issues like fatigue, depression and psychological trauma resulting from the stress involved in combining the two roles were noted in the study. This is in line with previous studies conducted by Firth-Cozens (2003), Keene and Quadagno (2004), and Wong (2008), which suggested that the occupational workload of the medical profession is huge and thus female doctors become fatigued and drained and unable to perform their roles in the family at the end of their daily shifts. This finding also resonates with Noor (2002), on the argument that when people devote too much time to work, there is every likelihood that other function would be negatively affected. 
Above all, while some participants see their role of doctor as a calling, others see it as a means to raise their status as women. Nevertheless, the majority of the participants confessed that they actually engage in the dual role to help increase the family income. These findings rest on the view of Choji (2012), regarding the changing role of the woman in the family.

\section{Conclusion and Recommendations}

The study explored the conflicting role of female doctors as mothers and wives in the family. The objectives of the study included: to know if female doctors provide psychological and emotional support for their families, to know who fills the gap, to know if the dual role affects their health and to determine who is to blame for their predicament. This study used the traditional qualitative method of inquiry which includes an exploratory and explanatory case study approach to unravel the difficulties confronted by the Nigerian female medical doctors in their attempt to balance their work and family lives obligations.

The study focused on a group of participants, which were married medical doctors. The study was conducted among doctors in three tertiary hospitals in Nigeria: Bowen Teaching Hospital, Ogbomoso, Oyo State; Ladoke Akintola University of Technology, Oyo State and University of Ilorin Teaching Hospital, Kwara State. 15 married doctors were involved in the study cutting across House officers, Medical Officers, Residents, Senior Residents and Consultants, while information was retrieved from participants through unstructured in-depth interviews.

Findings revealed that many female doctors in Nigeria are not able to effectively occupy their role as a mother and wife in the family as a result of the role conflict with their professional status. The study recommended that, since women have vital roles to play in ensuring the continued existence of the family and the society at large, and at the same time pursue careers of their choice, women in Nigeria should endeavor to balance their roles as career women at work and wives in the family.

\section{References}

1. Aaron-Corbin, C., 1999. The Multiple role balancing act. Management Review, 88(9), pp. 6270.

2. Adepoju, A. and Mbugua, W., 1997. The African Family. An overview of changing forms. In: A. Adepoju, ed. 1997. Family, population and development in Africa. London: Zed Books. pp.41-59.

3. Aina, I. O., 1998. Women, culture and society. In: A. Sesay \& A. Odebiyi, eds. 1998. Nigerian women in society and development. Ibadan, Nigeria: Dokun Publishing House/INTEC. pp. 3-33.

4. Amazu, A. in dialogue with Fr. Omexiri. Nigeria: Female Doctors, Indefatigable. Copyright (C) 2008 Daily Champion. January 25, 2008. Available online from: http://allafrica.com/stories/200801250261.html [Accessed 22 January 2018]

5. Aweda, A. D., 1984. Sex-Role Inequalities in the African Family: Contemporary Implications. Ife Social Sciences Review, 7(1 \& 2), pp.188-197.

6. Bernard, J., 1981. The Good-Provider role: Its rise and Fall. American Psychologist, 36(1), pp.112.

7. Burke, R. J., 2009. Cultural values and women's work and career experiences. In: R. Steers and R. Bhagat, R., eds. Handbook of cross-cultural research. Cambridge: Cambridge University Press, pp.442-461. 
8. Carlson, D.S, Kacmar, K. and Stephina, L.P., 1995. An examination of two aspects of workfamily conflict: Time and identity. Women in Management Review, 10 (1), pp.17-25.

9. Carrigan, T., Connell, B. and Lee, J., 1987. The 'Sex-Role' Framework and the Sociology of Masculinity in G. Weiner and M. Arnot, eds. Gender Under Scrutiny: New Inquiries in Education. London: Hutchinson in association with the Open University.

10. Choji, R., 2012 Nigeria: Women Are Taking Over the Role of Bread Winner in Nigeria., Copyright (c) 2012 Leadership, July 24. Available from: http://allafrica.com/stories/201207250512.html. [Accessed 17 July 2017].

11. De Ruyter, K., and Scholl, N., 1998. Positioning qualitative market research: reflections from theory and practice. Qualitative Market Research, 1(1), pp.7-14.

12. Dyrbye, L. N., West, C. P., Satele, D., Boone, S., Tan, L., Sloan, J., Shanafelt, T. D., 2014. Burnout among U.S. Medical Students, Residents, and Early Career Physicians Relative to the General U.S. Population. Academic medicine, 89(3), pp.443-451.

13. Emslie, C., Hunt, K. and Macintyre, S., 2004. Gender, work-home conflict, and morbidity amongst white-collar bank employees in the United Kingdom. International Journal of Behavioral Medicine. 11(3), pp.127-134.

14. Emslie, C. and Hunt, K. 2009. Live to work or work to live? A Qualitative study of gender and work-life balance among men and women in midlife. Gender work and Organization, 16 (1), pp.151-172.

15. Ering, S. O., Akpan, F. U., and Emma-Echiegu, N., 2014. Mothers Employment Demands and Child Development: An Empirical Analysis of Working Mothers in Calabar Municipality. American International Journal of Contemporary Research, 4(4), pp.184-191. Available from: http://www.aijcrnet.com/journals/Vol_4_No_4_April_2014/24.pdf.[Accessed 11 July 2017].

16. Etim, J. J., Bassey, P. E., Ndep, A. O., Iyam, M. A., Nwikekii, C. N, 2015. Work-related stress among healthcare workers in Ugep, Yakurr Local Government Area, Cross River State, Nigeria: a study of sources, effects, and coping strategies. International Journal of Public Heath, Pharmacy and Pharmacology, 1(1), pp.23-34. Available from: http://www.eajournals.org/wpcontent/uploads/Work-----Related-Stress-among-Healthcare-Workers-in-Ugep-Yakurr-LocalGovernment-Area1.pdf. [Accessed 23 January 2018].

17. Fapounda, T.M., 2014. A Comparative Study of Work-Family Balance of Female Journalists and Nurses. International Journal of Research in Humanities and Social Studies, 1(1), pp.77-82. Available from: http://www.ijrhss.org/pdf/v1-i1/10.pdf. [Accessed 12 July 2017].

18. Firth-Cozens, J., 2003. Doctors, their wellbeing, and their stress. BMJ , 326, pp.670-671.

19. Gjerberg, E., 2003. Women doctors in Norway: the challenging balance between career and family life. Social science \& medicine, 57(7), pp.1327-1341.

20. Gordon, M., 1998. Role Theory. In: Oxford Dictionary of Sociology. Oxford, New York: Oxford University Press.

21. Gryzwacz, J. G. and Carlson, D. S., 2007. Conceptualizing work-family balance: Implications for practice and research. Advances in Developing Human Resources, 9(4), pp.455-471.

22. Hansen, S. L. and Ooms ,T., 1991. The Economic Costs and Rewards of Two-Earner, TwoParent Families, Journal of Marriage and Family, 53(3), pp.622-634.

23. Humm, M.,1989. The Dictionary of Feminist Theory. London: Harvester Wheatsheaf.

24. Fuß, I., Nübling, M., Hasselhorn, H.-M., Schwappach, D. and Rieger, M. A., 2008. Working Conditions and Work-Family Conflict in German Hospital: Physicians Psychosocial and Organizational Predictors and Consequences. BioMed Central Public Health, 8, pp. 353.

25. Jacobs, J. and Gerson, K., 2004. The time divide work, family and gender inequality. Cambridge, MA: Harvard University Press. 
26. Johnson, W. D., 1991. Predisposition to emotional distress and psychiatric illness among doctors: The role of unconsciousness and experimental factors. British Journal of Medical Psychology, 64(4), pp.317-329.

27. Keene, J. R. and Quadagno, J., 2004. Predictors of perceived work-family balance: gender difference or gender similarity. Sociological Perspectives, 47(1), pp.1-23.

28. Kitching, B. and Woldie, A. 2004. Female Entrepreneurs in Transitional Economies: a comparative study of Businesswomen in Nigeria and China. In: 4th annual Hawaii International Conference on Business, 21-24 June 2004, Honolulu, Hawaii. Available from: http://eprints.qut.edu.au/1168/. [Accessed 12 July 2017].

29. Kramarae, C., 1992. The condition of Patriarchy. In: Kramarae Cheris and D. Spender Dale, eds. The Knowledge Explosion: Generation of Feminist Scholarship. Athen Series, London: Teachers College Press.

30. Kroska, A., 2004. Divisions of domestic work: Revising and expanding the theoretical explanations. Journal of family issues, 25(7), pp.900-932.

31. Lerner, G., 1986. The Creation of Patriarchy. Oxford: Oxford University Press.

32. Lewis, J., 1997. Lone Mothers in European Welfare Regimes: Shifting Policy Logics. London, Philadelphia: J. Kingsley Publishers.

33. Levey, R. I., 2001. Sources of Stress for Residents and Recommendations for Programs to assist them. Academic Medicine, 70(20), pp.142-150.

34. Nogueira-Martins, L. A., Stella, R. C., Nogueira, H. E., 1997. A pioneering experience in Brazil: the creation of a center for assistance and research for medical residents (NAPREME) at the Escola Paulista de Medicina, Federal University of São Paulo. Sao Paulo Medical Journal, 115(6), pp.1570-1574.

35. Lussier, G., 2002. Support Across two Generations Children's Closeness to Grandparents following Parental Divorce and Remarriage, Journal of Family Psychology, 16(1), pp.363-376.

36. Makama, G. A., 2013. Patriarchy and gender inequality in Nigeria: the way forward. European Scientific Journal, 9(17), pp.115-144. Available from: www.eujournal.org/index.php/esj/article/download/1161/1177. [Accesssed 17 July 2017].

37. Noor, N., 2002. Work-family conflict, locus of control, and women's well-being: test of alternative pathways. The Journal of Social Psychology, 142(5), pp.645-66.

38. Odle-Dusseau, H. N., Britt, T. W., and Bobko, P., 2012, Work-family balance, wellbeing, and organisational outcomes: investigating actual versus desired work/family time discrepancies. Journal of Business and Psychology, 27(3), pp.331-343.

39. Odunaike, B. A., 2012. Role Conflict among Women in Intercontinental Bank Plc, Lagos State. Global journal of human social science sociology, economics \& political science, 12(9), pp.2328. Available from: https://socialscienceresearch.org/index.php/GJHSS/article/view/457/408 [Accessed 10 January 2018].

40. Okonkwo, A. E., 2012. Strain-based family interference with work and feeling of reduced personal accomplishment among mothers in human service profession. In: Work and Family Researchers Network Conference, 12-16 June 2012, New York, USA. Available from: https://workfamily.sas.upenn.edu/wfrn-repo/object/d0ee5zl2yj0qq0he [Accessed 19 November 2017].

41. Onasoga, O. A., Ogbebor, S. O. and Ojo, A. A., 2013. Occupational Stress Management among Nurses in Selected Hospitals in Benin City, Edo State, Nigeria. European Journal of Experimental Biology, 3(1), pp.473-481. 
42. Perlow, L. A and Porter, J., 2009. Making time off predictable and required. Harvard Business, 87(10), pp.102-110. Available from: http://hbr.org/2009/10/making-time-off-predictable-andrequired [Accessed 17 July 2017].

43. Pilinger, J., 2002. The politics of the time: can work-life balance work? Equal Opportunities Review, 107(2), pp.18-21.

44. Rehman, S., and Roomi, M. A., 2012, Gender and work-life balance: A phenomenological study of women entrepreneurs in Pakistan, Journal of Small Business and Enterprise Development, 19(2), pp.209-228.

45. Rubery, J., Smith, M., Fagan, C., and Grimshaw, D., 1998. Women and European Employment. London: Routledge.

46. Silberschmidt, M., 1999. Women Forget that Men are the Masters Gender Antagonism and socio-economic change in Kisii District, Kenya. (C) The author and Nordiska Afrikairstitutet, Stockholm: Elanders Gotab.

47. Stacey, J., 1993. Untangling Feminist theory. In: D. Richardson and V. Robinson, eds. Introducing women's Studies: Feminist Theory and Practice. $1^{\text {st }}$ Edition, London: Macmillan. pp.49-73.

48. Stocvk, R., 1995. Africa South of the Sahara: a Geographical Interpretation. New York: Guilford Press.

49. Verlander, G., 2004. Female Physicians: Balancing Career and Family. Academic psychiatry, 28(4), pp. 331- 336.

50. Walker, E., Wang, C., and Redmond, J., 2008. Women and work-life balance: Is home based business ownership the solution? Equal Opportunities International, 27(3), pp. 258-275.

51. Wolfe, L., 2017. How Women Overcome Challenges in Business. Available from: https://www.thebalance.com/challenges-facing-business-women-working-moms-3514902. [Accessed 22 January 2018].

52. Wolfe, L., 2017. How Women Overcome Challenges in Business. The Balance. Make money personal., 17 July. Available from: https://www.thebalance.com/challenges-facing-businesswomen-working-moms-3514902. [Accessed 22 January 2018].

53. Wong, G. S. W. J., 2008. Doctors and Stress. Medical Bulletin, 13(6) Available from: http://www.fmshk.org/database/articles/03mb1_3.pdf. [Accessed 17 July 2017].

54. Wusu, O. and Abanihe, U. C., 2007. Interconnections of Changing Gender Role, Socialization and Youth Sexual Behaviour in Badagry: Youth's View. Lasu Journal of Social Sciences, 6(1), pp.244-261. 